\title{
the hand that writes community $\mid$ in blood
}

In late August 2001, the Australian Government prohibited 433 Afghan refugees, rescued from their sinking boat by the Norwegian freighter the Tampa, from landing on its shores in an attempt to stop the flow of 'people smuggling' via our Indonesian neighbours. While these asylum seekers, and other boatloads since, have been relocated to Pacific islands to await a decision about their fate, a heated public debate has erupted on shore between those who would support any move to seal the borders of our community against a perceived foreign invasion and those who view this stand by its government as a national disgrace (and a cynical move to win the impending federal election, held two months later, on a wave of apparent racism, fear and misplaced nationalism solicited by the government's action). The fact that Afghanis have inhabited Australia since the 1840s and that they have sought refuge more recently because of an oppressive (Taliban) regime born from and sponsored by the military and economic activities of the 'West', seemed to be lost on those who perceive these refugees as foreign and who claim that their fate has nothing to do with us. The ramifications of this event on both the multicultural fabric of Australian society and on the thousands of asylum seekers who already inhabit detention centres around Australia have been extraordinary and have continued to escalate as the government dug in its heels and as fears grew with the emotional, military and legislative impact of the events of September 11. The effects have been expressed most obviously in the bodies of everyone who has a stake: in the passionate anger and fear of those who applaud the government's stance; in the cold stony-faced defensive stance of the Minister for Immigration; in the shoulders, hunched in shame, of those who oppose the government's stand; and, most worryingly, in the lips of detainees, lips tasting poison and roughly sewn together in protest. The Australian Prime Minister John Howard has called this 
form of protest 'moral intimidation'. Perhaps a better description would be moral implosion. For if these bodies signify anything it is a loss of meaning and with this the dissolution of the body of community in the wake of the Prime Minister's attempt to unify his own.

One obvious point that this Australian response to asylum seekers illustrates is that as much harm as good can be done in the name of community. More fundamentally it begs the question: what is the meaning of a community that would make such a public display of excluding the foreign and would back this up by protecting itself through advocating pre-emptive strikes against strangers? There is a glaring contradiction between the egalitarian, humanitarian, democratic and other values said to hold this community together, and the means it advocates for protecting these values. Another related contradiction is: why, for instance, do policies of exclusion, aimed at protecting the unity of community, actually effect internal divisions and why do such policies affect not only the meaning and existence of the bodies of those targeted but also the bodies they are meant to unify and protect? In attempting to answer these questions this essay proposes that community is about the sharing of meaning, but not at the expense of difference; community is not a unity of shared meanings that at best tolerates difference, but rather community lives from difference. ${ }^{1}$ Drawing on the metaphor of the handshake to signify the 'bond' of community, I will first propose that community is built through the hand that extends a welcome to a stranger who it cannot grasp. ${ }^{2}$ Second, it will be proposed that it is through the social expression of bodies that the circulation of meaning, essential to sociality, takes place. Borrowing the metaphor of blood to signify the life force of the circulation of meaning, it will be argued that it is through the cut of the touch (actual and at a distance) of other ungraspable bodies, that community begins, bodies take shape, meaning is produced, and the difference between bodies necessary to the expression of meaning is maintained. ${ }^{3}$ Finally, the essay also explores the point at which the cut that opens bodies to each other in community turns into symbolic and physical violence. This point would be the limit where there is either too much or not enough blood to keep the expression of meaning going. This is the ethical point where the limit between bodies dissolves with an attendant moral implosion and a dissolution of meaning.

I propose this account of community formation, which finds bodies, ungraspable difference and the expression of meaning inextricably linked, in order to address a neglect of the sociality of the body in current models of community. That neglect, I submit, explains why some models of community, while keen to promote multiculturalism and tolerance of difference, can tend toward the opposite. This is true of communitarianism and related models that would base community on the commonality of meaning and unity of identity. Against the emphasis on individualism in liberal political theory, communitarians understand community to be built 
through shared practices, dialogue, common social meanings and traditions, and on the interrelation, mutual recognition, and knowledge of the other as derived from a Hegelian notion of identity formation. Without denying the importance of being-with to the formation of identity and a sense of belonging, this formula for basing community on finding or forging commonality between rational minds tends to assume that the body of the community is already in place as unified and coherent prior to the welcome of the other and that the other can be either grasped in the handshake or, if too foreign, fended off with a hand raised in selfdefence. Charles Taylor, for example, claims that identity is communal and dialogical rather than individual, that it is based on shared values, language, and mutual recognition and understanding. ${ }^{4}$ However, he assumes the unity of identity and difference through this process so that the identity and meanings one shares with others in community is sufficiently stable and the values that constitute it are sufficiently explicit. One community, always ours, can recognise and judge the values held by another minority group in deciding whether they are worthy of political recognition and/or inclusion in one's own community. 5

Such a model of community is reflected in the politics of exclusion being practised by many Western democratic governments that, for example, are justifying new policies of shutting out all asylum seekers and refugees in terms of protecting the values and security of their own communities. The Australian Prime Minister, John Howard, implicitly drew on such a model of community when he said, in accusing one group of asylum seekers of throwing their children overboard, that we would not want in our community people who would treat their children in this way. Even if that comment were not based on a lie, it was based on assumptions about commonality that do not hold up even under cursory scrutiny. It assumes that 'they' hold values in common with each other that include putting children's lives at risk and it assumes that 'we' are bound together by an opposite value that could be located in practice. If asked to take a stand on whether we make a habit of throwing children overboard, I am sure we would say no; but faced with similar circumstances, stranded on an ocean in a leaking fishing boat, who of us could say for sure that we would not hoist our children over first before saving ourselves. 6 But neither Howard nor Taylor attend to the contextual and ambiguous nature of the expression of meaning when it comes to judging the actions of others already assumed to be too foreign. There is no acknowledgement here of the possibility that the meaning expressed by an individual or community is multifaceted, open, and unfinished; that the social meanings, values, and traditions that seem to hold together one's own community are therefore neither stable nor easily locatable; and that what drives community in the first place is a relation to difference that would be effaced if unity and mutual recognition were ever fully realised. This emphasis on social unity, on judging with conviction the strangeness of communities other than our own, and the attendant failure of communitarianism to recognise the internal multiculturalism and ambiguity of meaning of what we might call 'our' 
community, is one reason that it has been charged with ethnocentrism. ${ }^{7}$ It is this idea of community built upon commonality behind a wall that would keep strangers out that overlooks the link between the body, alterity, and the expression of meaning in the formation of community.

Questioning the centrality of commonality as the basis of community, which is part of the aim here, is not to deny the importance of community understood as a sense of belonging and the being-with others upon which it is based. Indeed I would argue, against some postmodern models of dispersed identity, that no one lives without a sense of belongingthat pre-reflective sense of having a world with others that allows me to carry on without thinking. Nothing makes me feel more at home than a shared joke, a familiar taste, shared outrage at Howard's latest bit of social policy, and music that has a beat that I can dance to. And in case that suggests that community, as a sense of belonging, belongs only to the privileged, Catherine Robinson argues that it also belongs to the homeless, although in that case familiarity would be built through the sharing of strategies to avoid surveillance and violence, perhaps the sharing of needles, and the unreflected certainty of finding the same soup van on the same corner in the evening. ${ }^{8}$ Phenomenologists such as Merleau-Ponty and Heidegger in his early work would say that this sense of belonging arises from being-with others within a horizon of social meaning that makes the pre-reflective perception of others and the world possible. But, against communitarianism, the idea that I dwell with others within an already socially significant world is not the same as saying that I can isolate and point to those meanings and values that inform my sense of belonging, or my perception, or that I hold these values in common with others absolutely. This sense of belonging is located not in a table of shared values that I hold in my mind, that I can list off at will, or that I use to identify with or recognise in others; rather, this familiarity is located in my body as an atmosphere that informs my perception of the world and of others. For Merleau-Ponty, for example, meaning is inherited, incarnated, and expressed pre-reflectively such that every body is a style of being, a signifying and signified expression of comportment toward a world. ${ }^{9}$ Or, as Nietzsche puts it, a person has 'selected and breathed life into their means of expression, not by chance but of necessity, in accordance with [their] morality'. 10 This morality (meaning and the moral values it may carry) takes hold of me, as Moira Gatens argues, through imaginary bodies, through the construction of various forms of subjectivity by social ideas about bodies and their relations. ${ }^{11}$ Hence, my style of being, which is also a mode of expression, is informed by culturally sedimented meaning. But this morality does not breathe life into my mode of dwelling in the form of abstract ideas that I accept or reject through acts of conscious judgment or that capture the whole of my being. Rather this meaning comes to me and is incarnated through habituated dwelling with others, in incarnated fragments from the bodies of others; through gestures that condemn with the curl of a lip or affirm with a wink and a smile; or 
through words that shame with timbre and tone; or affirm with a pat on the back. And this incarnation and expression of social meaning is ambiguous and open to transformation for reasons I will address.12

It is because the body expresses existence and meaning as it actualises existence and meaning that it is so hard to locate the meanings and values that drive us and that we assume we share with others. This meaning exists most fundamentally through the bodies that express it through other bodies. This is not to deny that social meanings and values have institutional support through written laws and principles (of democracy, justice, equality etc.). But here too these principles and laws are expressed and actualised through the bodies that write, govern, enact, monitor, and interpret the law. That meaning is actualised and expressed by a body through other bodies is why I can only grasp a sense of belonging to one or several communities, and then only in passing, not by pointing to a table of ideas, but as I live these ideas with and in relation to other bodies; and then I only grasp these most explicitly in retrospect when I feel a failure of belonging with others: when I find my local cinema invaded one day by a group of blokes with baseball caps worn backwards, or when I am passed over for service in favour of a younger person, or if I were refused entry on the basis of sex or the colour of my skin. That meaning is expressed and actualised through bodies is one reason why a politics of exclusion, such as that being practised by the Australian and other conservative democratic governments, tends to be internally divisive and destructive: as values and meanings do not exist apart from their expression through bodies, then no one actually lives up to those abstract values alone in practice and they can only be articulated by pointing to instances where they supposedly fail-in those others we would exclude from our community ahead of any contact on the basis of what is perceived as foreign in terms of values thought to adhere to race, class, sexuality, country of origin, religion (in drowning asylum seekers, in radical homosexual high court judges, in lesbians who use IVF, in the unemployed, to name a few targets of the politics of exclusion practised by members of the current Australian Government). The problem with justifying a politics of exclusion with reference to ideas and values supposedly shared by our community but abstracted from their expression through bodies is that such ideas necessarily exclude every actual body to eventually leave a community of one. But, related to this point and more central to my purposes, it is because the body expresses meaning as it actualises existence, only with and through other bodies that are different to mine, that identity and community are internally multifaceted, fragile and open, rather than unified, secured by commonality, and completed. It is paradoxically difference expressed in the relation of being-with other bodies, rather than commonality, that drives community and its sense of belonging. Community lives on difference, on the touch of difference of other bodies that cannot be assimilated to mine. I want to dwell on this point for a while, beginning with what I do not mean. 
In claiming that community lives on difference expressed in the relation of being-with other bodies that I cannot assimilate, I do not mean what Iris Marion Young has described as a 'community of strangers' under the label of a postmodern politics of difference. Young, in an early but groundbreaking and influential discussion of community based on commonality versus a politics of difference defines the latter as 'openness to unassimilated otherness'.13 I have no quarrel with this definition. But in articulating what she means she describes her ideal of a city of strangers, which exhibits 'temporal and spatial distancing and differentiation' characterised by endless unique spaces and populated by strangers who are 'externally related. [These strangers] experience each other as other, different, from different groups, histories, professions, cultures, which they do not understand'. ${ }^{14}$ The attraction of such a city for Young is the diversity of spaces, subcultures, and activities that one can enjoy with anonymity and without imposing one's values on others, as if I could touch the surface in passing while remaining untouched. While this idea of diversity, externality, and anonymity is what also appeals to me about the city, I doubt this could be enjoyed if it did not already mean something to me, if I had not already been touched by others, if I did not already have the benefit of the sense of belonging that I described before. This familiarity that comes from the habit of dwelling with others, and the being-touched that this involves, would therefore also be in operation in the apparent anonymity of dwelling with strangers that Young describes. For Young it is as if difference is already constituted and contained within unique meaningful capsules for me to touch or not, understand or not, accept or reject at will. This difference is not what I mean when I say that community lives from difference. The difference community lives from is not subject to choice and does not leave me or the other untouched. Nor do I mean that identity, communal or individual, is multifaceted in the sense of being the product of intersections with many different modes of being. As the above discussion of belonging indicates, identity is 'intersectional' or 'hybrid' in the sense that my habitual ways of expressing and patterning existence do arise from dwelling with different kinds of bodies, from having feet and hands in many different communities which differ on the basis of sex, race, sexuality etc. such that, as Chantal Mouffe puts it, identity arises from 'intricate links between many forms of identity and a complex network of differences'. 15 But the difference that identity and community live from is not difference understood as already meaningful characteristics that intersect across my body and come to settle upon and in it such that I am 'contaminated by this otherness'. 16 This intercorporeal or shared belonging is relevant to the difference community lives from and I will return to address the connection between them.

The difference community lives from is the other's difference that I cannot grasp but that initiates my movement towards the other and towards the world. Levinas, for example, puts this difference in terms of the other's alterity that 'initiates the handshake' of sociality. ${ }^{17}$ The other's alterity (apart from any particular expression or interpretation of difference that this 
alterity may inspire) touches me, affects me, cuts me, and opens me to the other and to the world. This is the ungraspable difference that is the condition of community, of being-with. The individual does not come before this sociality. Rather, the other's alterity is the condition of my unique identity and subjectivity: I am this unique exposure to, welcome of, and giving to the other whom I cannot know. This relation to alterity, the hand extended to the other, is corporeal and affective: it is the strangeness of others that I feel, rather than anything that I recognise, judge, or understand, that moves me to act and speak in the first place and, so, opens me to the other. And this affective response to the other is also where both signification and ethics originate. The other's 'absolute' otherness signifies (through the face and, as Levinas sometimes admits, the whole of the body) a 'unique sense' that inaugurates and situates meaning. 18 That is, the other's otherness signifies their unique value (apart from and before the assignment of any cultural meaning to this difference), by signifying their absolute difference to me as a site of expression and hence their vulnerability and resistance to my projects and judgments. This expression of uniqueness or 'signifyingness of the face' thereby puts existence on a human and moral plane; it says 'thou shalt not kill' and this unique sense introduces value and meaning into existence by also soliciting my response through discourse (I speak and give to the other rather than kill or possess). My cultural expression, including the hand extended to the other, would not arise at all, says Levinas, without this orientation towards the absolute otherness or unique sense of the other 'whose presence is already required for my cultural gesture of expression to be produced'. 19 So, through this affective and ethical relation to alterity, my self-possession is cut open in a way that not only makes me responsible for the other who moves me, but also opens me to the other through discourse whereby I offer the gift of a common world.

Not only is the community of being-with initiated and maintained by this unique sense or absolute difference, but so are our humanitarian and egalitarian principles. It is a principle of existence (and not a peculiarity of a select group of culturally specific modes of belonging) that we would preserve the other's unique sense by building a meaningful world in which it would better survive rather than negating or killing it off. It is on this basis that Levinas claims that the ethical relation (the hand extended to the other who it cannot grasp) orientates politics toward justice.20 What he does not address adequately is the reverse relation, how existing modes of belonging (including their intercorporeal basis) and the social horizons of meaning they express may already inform this ethical relation to difference from which community lives.

While Levinas sometimes suggests otherwise, the alterity or unique sense that initiates and maintains community is not detached from the expressive bodies that it links and animates, or from the history, politics, and horizon of social meaning within which these bodies dwell.21 Merleau-Ponty, for instance, also notes a unique sense (what he calls 'singularity') that animates 
my opening onto the other, my being-with the other and vice versa, but for him this arises within the expression of my style of existence through the other's body.22 It is the body as expression that signifies its singularity, that is, the body as expression signifies that the other is a unique mode belonging to the world that is not me. It is being touched by this absolute difference of the other's body (actually or at a distance) that opens my body to the circulation and expression of meaning through the other's body (and vice versa). This difference not only inaugurates the expression of my body within an existing social horizon of meaning such that it and the world it belongs to mean anything at all, but it is also that strangeness that prevents both my body and the body of the community from being a unity and making complete sense from the moment of its appearance. Perception (pre-reflective and reflective) and written and spoken discourse amount to touching this being-touched. 23 What we perceive, think or write is written in our blood, it is an affective expressive offering of our body to the other whose absolute difference (uniqueness) inspires and moves us. But both I and the other bring to this encounter styles of existence that express culturally sedimented meanings which will effect degrees of familiarity and surprise depending on how much history we have in common. Whatever the degree of shared cultural background or common pre-history, touching my being-touched involves the sharing of meaning. In that blood donation the skin that holds our self-possession is broken; we cannot easily tell the difference between what touches and what is touched, what is me and not me, what meaning comes from me and what comes from the other. At the same time, while a sense of belonging to a world thus involves bodies inhabiting each other with an attendant sharing of meaning, the singularity or difference between me and the other, between the touching and being-touched, must be maintained for perception or the expression of meaning to take place at all. Merleau-Ponty calls this the 'paradox of expression' and the 'divergence of flesh'-the separation and merging of bodies as expression necessary for the expression of meaning that is community as being-with. ${ }^{24}$

This paradox of expression means that the 'other is never present face to face', 25 either in the communitarian sense of mutual recognition or in Levinas's sense of an originary exposure to the other's alterity prior to the social expression of bodies-between my body and the other's, between the touching and being-touched, is always the 'thickness of flesh', the difference between bodies that opens within and animates social expression. ${ }^{26}$ It is because of this paradox that I can never grasp the other's difference or the social meanings that are expressed in my belonging. Further, the paradox of expression is such that the body and its expression is real-ised ambiguously and unfinished in this writing of community between the touching and being touched. So, while the expression of my body is informed by culturally sedimented meanings and is lived as a sense of belonging, because perception and its verbal or written expression is animated by being-touched by another body (by the difference of the matter at hand that touches me), then the meaning of what I write in my blood in response 
is opened and transformed by the difference that provokes it. My body and existing social meanings it expresses, including any 'common pre-history' I share with the other, are prolonged but also surpassed in this community of being-with. 27 Something that matters moves me in its difference, and while I find the words and the actions to respond from the social horizon within which I dwell, I also find my body, my blood and its meanings, is opened by and flows toward the other and so is not yet finished. Community, as the sharing of meaning between bodies, is always inhabited by its undoing, familiarity by strangeness, sense by nonsense. This sharing of meaning is a two-way process that involves the open unfinished transformation of bodies and meaning and, most fundamentally, is dependent on maintaining the divergence between bodies necessary to keep expression going.

What explains a failure of belonging then, when confronted with strangeness (the baseball caps worn backwards, for example) is not the ungraspable difference between bodies that community lives from (if there were not this difference I would not feel or in other ways perceive and express the failure), but a refusal or denial of the ambiguity and unfinished transformation of meaning that this difference demands. What would explain such a failure in the expression of meaning, in the first instance, is a clash of styles accompanied by a degree of habit and sedimentation of meaning that makes it difficult in the short term for me to adjust to, tolerate, or welcome the strangeness that confronts me. Merleau-Ponty, from his earliest work, stresses that my freedom to be open to anything at all is necessarily limited by my pre-history, by the cultural sedimentation of meaning that informs my style of belonging. 28 There is nothing inherently wrong or unethical with a retreat into the familiar of this prehistory where I would reassemble myself accordingly. It happens all the time. (Although this retreat from others is never complete if I am still alive and if life means anything at all.) What matters about a failure of belonging is not that we are prone to the experience itself, but the conditions under which it happens and how one responds. There are situations where withdrawal from the strangeness of others into the familiar, for instance, would not only be explicable but also justified: If the strangeness that confronts me already involves a refusal of the paradox of expression, a strangeness that fixes meaning and is expressed as vilification, violence, appropriation or some other form of explicit negation of me as a unique expression of existence. Conversely, the withdrawal from others effected by a failure of belonging because of a clash of styles or by the perceived possibility of such a failure would be a problem, for example, if it became a matter of policy, either personal or political. Both cases involve closing down the difference between bodies from which community lives. It is to the ethics of that closure that I now turn.

I turn more directly to the ethics that attends this idea that community and its undoing take place in the ambiguous expression of meaning between bodies in order to address the suggestion with which I began: that an implosion of meaning and a moral implosion are 
precipitated by attempts to build or maintain community, as a politics of exclusion does, on the assumption of commonality and shared values against others who are perceived as foreign. On the model of community that I have just outlined, what Jean-Luc Nancy would call 'community without communion',29 bodies and their social expression are what matters to both sociality and to what some might call human dignity. It is as bodies that we actualise the social meaning we inherit, it is as a corporeal mode of belonging to a world that we are unique, and it is as bodies that we are mortal, finite, and vulnerable. It is this mortality and finitude (uniqueness) of the body then that makes us 'human', social, and therefore moral beings. 30 As I suggested earlier, this is why 'thou shalt not kill' is arguably such a fundamental moral value. But, as I also suggested above, it is from the corporeal foundation of finitude and sociality that our other 'humanitarian' principles arise, that is, it is on the basis of the corporeal foundation of finitude and sociality that we have a responsibility to welcome the bodies of others without eradicating their uniqueness. In other words, as a body I only get my sense of mortality and finitude, and hence my uniqueness, from my community with others whose difference/uniqueness I cannot assimilate; this uniqueness is only signified in community and community lives from its expression. Attending to the ethics of community involves attending to both the necessity of extending one's hand to the other and the necessity of maintaining the difference or limit between bodies so joined.

Community then, as Jean-Luc Nancy puts it, is an original sharing and 'com-pearance' of singular (different and finite) beings exposed to each other. These singular beings are not individual identities that come before this 'exposition' in community-singular beings are finite beings exposed to their finitude through the otherness of others and this exposure is also exposition, that is, involves the expression and sharing of meaning. Hence:

A singular being does not emerge or rise up against the background of a chaotic, undifferentiated identity of beings, or against the background of their unitary assumption, or that of becoming, or that of will. A singular being appears, as finitude itself: at the end (or at the beginning), with the contact of the skin (or the heart) of another singular being, at the confines of the same singularity that is, as such, always other, always shared, always exposed $\ldots$

Community means, consequently, that there is no singular being without another singular being ...

[F]initude co-appears or compears (com-paraît) and can only compear: in this formulation we would need to hear that finite being always presents itself "together", hence severally; for finitude always presents itself in being-in-common and as this being itself. 31

This singularity that is also a being-in-common, or sharing that is also a division (partage) appears at the limit of the contact of skin. This limit of touching my being-touched is where 
both singularity and community arise. It is also the limit that marks the moral value of a singular body and is therefore the source of our ethics. Nancy elsewhere calls this limit 'absolute skin'.32 That is, the cut that forms and opens the body, that forms the hand extended to another body, that gets the circulation of blood going, arises from the touching itself. 'It is by touching the other that the body is a body' and it is through this touch that community takes place as bodies and meaning 'absolutely separated and shared'.33 Nancy's use of the term 'absolute' here and with reference to 'skin' refers to the idea that in the touch, in the limit that forms bodies as separate and shared, meaning takes place such that the body is (as opposed to has) meaning, apart from any interpretation of that meaning. Another way he explains this finitude or absoluteness of the body, reminiscent of Merleau-Ponty's idea of singularity, is that the other's body signifies another unique access to a world, another source of signification, that is not me and that I cannot access. 34 But, paradoxically, the body is this absolute place of meaning, only as being exposed to this finitude through others; only through being-touched (actual and at a distance) is the body the place of inalienable sense and hence unique value. Another way to put this might be to say that as bodies we are the unique event of the taking place of meaning and hence of value in itself, but only by 'exposition', by a sharing that exposes this uniqueness and allows its expression. The skin is absolute in the sense that skin marks the limit by which bodies appear as meaningful and singular/unique as well as shared. But neither this limit, this skin, nor the unique sense of bodies it expresses come before the touch of other bodies; the limit between bodies 'appears' with the touch. There is not first alterity detached from bodies and their social expression (as Levinas sometimes implies), but bodies detaching themselves from the limit of other bodies while remaining attached and exposed. 'To touch is to be at the limit.'35

It is the ambiguity and undefinability of this limit between bodies that makes the ethics of community difficult. That the body is the place of unique sense and yet makes sense only as such and more generally in community suggests that the body's exposition is inseparable from its social expression. The world is the 'exhibition' of bodies, as Nancy puts it. 36 Yet, the idea that the social world is the body's exposition is also its risk: there is the risk that a body's uniqueness will be deprived of exposition, and therefore that the body will be deprived of meaning, either through rejection by the bodies of others on the basis of perceived foreignness or through incorporation by other bodies, an appropriation that would also dissolve the limit. This dissolution of the limit and therefore of the absolute difference between bodies signifies the point at which the cut of the touch is too deep or is closed over so that the sharing of meaning necessary to the social expression of bodies is not sustained. If the contact of skin, touching and being touched, marks a limit between bodies made singular/unique and shared through the limit, then touch, as Nancy remarks in passing, is a matter of 'tact - that is to say, the right touch'. 37 
There are three related points I want to make about tact. First, through the limit marked by the touch of bodies my body is open and unfinished such that it owes its life to the blood of others it may now reject as foreign. I have a responsibility (to the life and value of my own body and those of others) to extend my hand to the other and welcome, with tact, that difference and the signification it brings. For, to paraphrase Nietzsche, the blood of another and the signs it gives can only survive if it is re-animated by the touch that it provokes: 'it is only our blood that constrains them to speak to us' and we honour the expressions of other bodies 'less by that barren timidity that allows every word ... to remain intact than by energetic endeavours to aid them continually to new life'.38 The body, singular and communal, signifies and lives through the 'interlacing, the mixing of bodies with bodies'39 and what this relies on is treating the other's uniqueness with tact. Yet, and second, this welcome of the other's difference is always conditional in two senses. The welcome is conditional in the sense that, as the sharing of meaning is two-way or reversible, so is the responsibility for maintaining the limit and hence the difference between bodies. There is no obligation here to welcome a body that lacks tact, that already negates my expression of existence, that presents as a hand that grasps or as a clenched fist. Welcoming the other's difference is also conditional in the sense that the way the hand is extended to the other is always accompanied by the sharing of meaning that provides the horizon of my sense of belonging. I will necessarily exceed the limit of the other's body by the touch, through the imposition of social meanings I already embody and through the transformation of modes of belonging that the sharing of meaning involves. While the hand extended to the other that it cannot grasp will always therefore involve a lack of tact, there are cases where it is clear that the limit has been exceeded in its formation to a point that is intolerable and therefore unacceptable. This brings me to my third point about tact - the point where the limit between bodies dissolves into symbolic or physical violence with an attendant dissolution of meaning.

All too easily bodies can lose their sense (and sense lose its bodies) through a lack of tact of bodies that completely withdraw from or exceed the limit of the other's touch. 'Deported, massacred, tortured' bodies are examples that Nancy provides. ${ }^{40}$ To this we might add raped, imprisoned, abandoned and vilified bodies. Within the act of rape, deportation, or vilification, and apart from any meaning imposed through the act, such bodies are being deprived of community and so are being stripped of their ability to signify their uniqueness and be the unique event of the taking place of meaning. This is also the case with a more general politics of exclusion. Such a politics would turn the paradox and ambiguity of expression, the separation and merging of bodies, or the singularity and sharing of meaning 'into a matter of exclusion' where the one practising such a politics seeks to be the singular origin of meaning. ${ }^{41}$ In Merleau-Ponty's terminology, this would be to turn the withdrawal from others precipitated by a failure of belonging into a policy of denying that the expression of meaning 
is shared, ambiguous and transformative. In this denial or refusal of the paradox of the social expression of bodies 'social dichotomising' arises, that habit of conquering ambiguity by perceiving others as absolutely other and projecting onto them all those moral, racial, sexual, and other characteristics one would exclude from oneself or from one's community. ${ }^{42}$ Conversely but equally, denial of the paradox of expression finds political support in policies that would conquer ambiguity by insisting on social unity through the exclusion or denial of differences: 'There is an abstract or rigid liberalism which consists in thinking that all men are identical.'43 A politics that, as a matter of policy, makes the other identical or absolutely Other, whether evil or divine, no longer appreciates the paradox of expression, the separation and merging of bodies at the origin and circulation of meaning, and hence the singularity of the other as meaning, as a unique belonging to the world that I cannot grasp. Instead, Nancy suggests, a politics of exclusion seeks to fix the meaning of the other, to 'fix the other ... in one place', in order to either become the origin of meaning or to expel any other expression of outside the world. ${ }^{44}$ It could also be said that such a politics seeks to be the origin of meaning by fixing the limit itself, the paradoxical border between bodies, by making the limit one of separation without sharing and deeming what does not belong this side to be absolutely foreign and not belonging anywhere or at all.

To what end then would someone brutalise bodies or reject them on mass? Raped, tortured and vilified bodies have been sacrificed in the service of securing some other body's mythical sense of unified identity. Bodies deported, incarcerated, and rejected on the basis of their foreignness only, by the Australian Government for example, have been sacrificed in the service of maintaining National unity by evoking a sense of shared and stable communal values. But these bodies have been 'sacrificed to nothing', as Nancy puts it. 45 The bodies of those asylum seekers have been sacrificed to nothing in so far as, in stripping the bodies of others of their ability to signify their uniqueness, we do not unify our own community by securing the limit between bodies. On the contrary, such treatment of others dissolves the limit between bodies necessary for the circulation and expression of meaning. This is because bodies signify their uniqueness and value through community, by being exposed to other bodies. In abandoning the bodies of others in such spectacular fashion, we dissolve the limit by which this exposition takes place. In dissolving this limit we lose our exposition, and dissolve 'our' community. At the same time we dissolve those humanitarian values upon which community is based-those principles signified by the hand extended to the stranger it cannot grasp, those values incarnated in attempts to build a world in which the uniqueness of others would better survive. If our treatment of bodies other than our own is such that they begin to lose sense then with this loss we not only make refugees of other ways of being but we also in the process reduce community and our selves to non-sense. This is why, I believe, policies of exclusion affect not just the bodies targeted but the bodies they are meant to protect; this is why, in an 
attempt to restore some meaning to the meaninglessness these policies effect, we will turn on each other and justify our position through vilification and violence. A politics of exclusion presents a picture of community with which community cannot live.

Rosalyn Diprose is a senior lecturer in philosophy at UNSW, Sydney. Publications emerging from her research on the corporeal basis of ethics and sociality include The Bodies of Women: Ethics, Embodiment and Sexual Difference (Routledge, 1994) and Corporeal Generosity: On Giving with Nietzsche, Merleau-Ponty, and Levinas (SUNY Press, 2002).

The thoughts laid out here have benefited from conversations and arguments with many regarding the issue of the Australian Government's treatment of asylum seekers. In particular I would like to thank Elizabeth Diprose, Moira Gatens, Genevieve Lloyd and Nikki Sullivan for challenging me to think through these issues with greater care than I may otherwise have done.

1. For another account of community in terms of difference (as opposed to unity and agreement) with particular reference to the Australian context see Linnell Secomb, 'Fractured Community', Hypatia, vol. 15, no. 2, 2000, pp. 133-50. Secomb's focus is on race relations between Indigenous and white Australians and while her analysis takes a different path to my own it has done much to inspire application of my work on the ethics of intercorporeality and sociality to concerns regarding Australian community.

2. For a more detailed comparative account of the 'bond' of community in terms of the metaphor of the handshake see Rosalyn Diprose, 'Community Through the Shaking of Hands: Levinas, MerleauPonty, and Nancy', in David Smith (ed.), The Phenomenology of the Body: The 20th Annual Symposium of the Simon Silverman Phenomenology Center, Duquesne University, Pittsburgh, 2002 (forthcoming).

3. For a more detailed account of expression specifically in terms of this metaphor of writing in blood see Rosalyn Diprose, 'Writing in Blood: Response to Helen Keane and Marsha Rosengarten, "On the Biology of Sexed Subjects", Australian Feminist Studies, vol.17, no. 39, 2002, pp. 279-82. For another account of the marking and reading of bodies in terms of the cut, but with particular reference to the tattooed body, see Nikki Sullivan's thought-provoking essay 'Reading Body Writing:
An Ethics of (Inter)Textual Pleasure' in Nikki Sullivan, Tattooed Bodies: Subjectivity, Textuality, Ethics, and Pleasure, Praeger, Westport and London, 2001, pp. 117-50.

4. Charles Taylor's seminal essay on this topic is 'The Politics of Recognition', in Amy Gutmann (ed.), Multiculturalism: Examining the Politics of Recognition, Princeton University Press, Princeton, 1994, especially pp. 32-6.

5. Taylor, p. 72.

6. I have deliberately elided at least two possible interpretations of what it may mean if these asylum seekers were throwing children overboard (which they weren't), based on the only two visual images made available of the alleged incident(s). One interpretation (the Prime Minister's) was that the asylum seekers were attempting to provoke the navy into taking them to the mainland by throwing their children into the sea; the other (more generous) interpretation was that the boat was sinking and they were following accepted procedure of evacuating children first. The point is that either interpretation depends on knowledge of context (which no one had), both interpretations would be contaminated with the experiences of the person making the judgment and by his or her expectations of the other, and whatever the interpretation it could not be said to imply anything about the values of a whole class of people. If the opportunity for judgment were 
reversed, for instance, would the Prime Minister accept that because some people or activities within 'our' community do put children's lives at risk, including arguably his own action regarding asylum seekers, that this points to a value that we all share?

7. For example Susan Wolf makes this charge in her 'Comment' in response to Taylor's essay in Gutmann, p. 84.

8. Catherine Robinson, 'Being Somewhere', Space and Culture, nos. $11 \& 12,2001$, pp. 7-23.

9. The works of Merleau-Ponty's that I will draw on particularly in elaborating a model of the intercorporeal expression of meaning are Maurice Merleau-Ponty, The Visible and the Invisible, trans. Alphonso Lingis, Northwestern University Press, Evanston, 1968; and 'Dialogue and the Perception of the Other', in The Prose of the World, trans. John O'Neill, Northwestern University Press, Evanston, 1973, pp. 131-46.

10. Nietzsche, 'Assorted Opinions and Maxims' (aphorism126), Human, All Too Human: A Book for Free Spirits, vol. 2, part 1, trans.

R. J. Hollingdale, Cambridge University Press, Cambridge, 1986, p. 242. For Nietzsche, all perception has a moral component, that is, is an expression of meaning contaminated by the values good or bad.

11. Moira Gatens, Imaginary Bodies: Ethics, Power and Corporeality, Routledge, London and New York, 1996, p.viii.

12. For a more detailed discussion of this point derived from Merleau-Ponty's model of perception and intercorporeality see Rosalyn Diprose, Corporeal Generosity: On Giving with Nietzsche, Merleau-Ponty and Levinas, State University of New York Press, Albany, 2002, chapter 5.

13. Iris Marion Young, 'The Ideal of Community and the Politics of Difference', Social Theory and Practice, vol. 12, no. 2, 1986, p. 22.

14. Young, pp. 20-1. Young has since revised her formula for a politics of difference and her definition of 'openness to unassimilated otherness'. I mention the earlier version to point to an individualistic pluralism and understanding of difference that still inhabits many accounts of a politics of difference and that I would distance my own account from.

15. There are a number of different versions of this important idea that identity is intersectional or hybrid. The one I am quoting from here is offered by Chantal Mouffe in 'For a Politics of Nomadic Identity', in George Robertson (ed.), Traveller's Tales: Narratives of Home and Displacement, Routledge, New York and London, 1994, p. 110

16. Mouffe, p. 110

17. Emmanuel Levinas, 'On Intersubjectivity: Notes on
Merleau-Ponty', in Outside the Subject, trans. Michael B. Smith, Stanford University Press, Stanford, 1994, p. 102.

18. Levinas's most sustained discussion of how this unique sense orientates meaning in a way that is ethical is in 'Meaning and Sense' in Emmanuel Levinas: Collected Philosophical Papers, trans. Alphonso Lingis, Martinus Nijhoff Publishers, Dordrecht, 1987, especially pp. 95-6, 88-9.

19. Levinas, 'Meaning and Sense', p. 95.

20. See, for example, Emmanuel Levinas, Totality and Infinity: An Essay on Exteriority, trans. Alphonso Lingis, Duquesne University Press, Pittsburgh, 1969, pp. 212-14.

21. For a more detailed critique of Levinas on this point see Diprose, Corporeal Generosity, chapter 9

22. See, for example, Merleau-Ponty's 'Dialogue and the Perception of the Other', in The Prose of the World, trans. John O'Neill, Northwestern University Press, Evanston, 1973, p. 141.

23. Merleau-Ponty's most extensive and fully developed discussion of this idea is in The Visible and the Invisible.

24. Merleau-Ponty, The Visible and the Invisible, pp. 131, 135, 139 .

25. Merleau-Ponty, 'Dialogue and Perception of the Other', p. 133.

26. Merleau-Ponty, The Visible and the Invisible, p. 135.

27. Merleau-Ponty, 'Dialogue and Perception of the Other', p. 141.

28. See for example the chapter on 'Freedom' in Merleau-Ponty's Phenomenology of Perception, trans. Colin Smith, Routledge and Kegan Paul, London, 1962, particularly pp. 454-5.

29. Jean-Luc Nancy, The Inoperative Community, trans. Peter Connor and others, University of Minnesota Press, Minneapolis, 1991, p. 144.

30. I am qualifying 'human' and 'humanitarian' with scare quotes because being a unique mode of belonging to a world is not necessarily restricted to what we ordinarily define as human; that is, it does not rely on any essential definition of what is involved in belonging to a world such as the capacity for thought, feeling, etc. All that is required for the body to signify this uniqueness is that it is expressed as such to others.

31. Nancy, The Inoperative Community, pp. 27-8.

32. Jean-Luc Nancy, 'Corpus' in The Birth to Presence, trans. Brian Holmes and others, Stanford University Press, Stanford, 1993, p. 205.

33. Nancy, 'Corpus', p. 204

34. Jean-Luc Nancy, Being Singular Plural, trans. Robert D. Richardson and Anne E. O'Byrne, Stanford University Press, Stanford, 2000, pp. 14-15.

35. Nancy, 'Corpus', p. 206.

36. Nancy, 'Corpus', p. 206.

37. Nancy, 'Corpus', p. 190. Nancy also mentions this 
idea of tact elsewhere, for example, in The Sense of the World, trans. Jeffrey S. Librett, Minnesota University Press, Minneapolis, 1997, p. 63.

Jacques Derrida provides a detailed analysis of Nancy's motif of tact in 'Le toucher', Paragraph, vol. 16, no. 2, 1993, pp. 111-57.

38. Nietzsche, p. 242.

39. Nancy, 'Corpus', p. 195.

40. Nancy, 'Corpus', p. 195.
41. Nancy, Being Singular Plural, p. 24.

42. Maurice Merleau-Ponty, 'The Child's Relations with Others', trans. William Cobb, in The Primacy of Perception, James M. Edie (ed.), Northwestern University Press, Evanston, 1964, pp. 103-5.

43. Merleau-Ponty, 'The Child's Relations with Others', p. 106.

44. Nancy, Being Singular Plural, p. 20.

45. Nancy, 'Corpus', p. 195. 